Document downloaded from:

http://hdl.handle.net/10251/161196

This paper must be cited as:

Cano, A.; Andrés, M.; Chiralt Boix, MA.; González Martínez, MC. (2020). Use of tannins to enhance the functional properties of protein based films. Food Hydrocolloids. 100:1-9. https://doi.org/10.1016/j.foodhyd.2019.105443

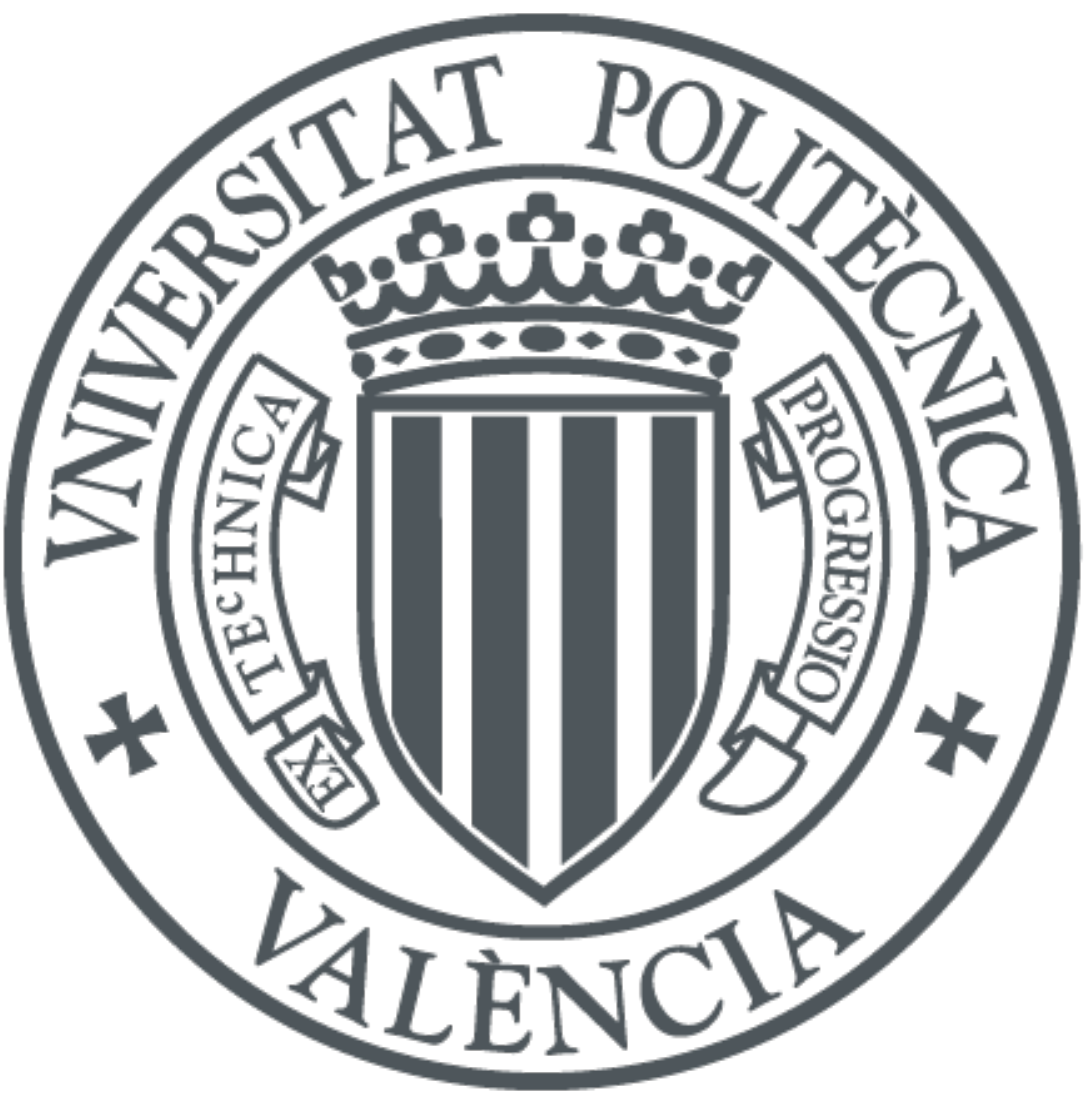

The final publication is available at

https://doi.org/10.1016/j.foodhyd.2019.105443

Copyright Elsevier

Additional Information 


\title{
Use of tannins to enhance the functional properties of protein based films
}

\author{
A. Cano, M. Andres, A. Chiralt, C. González-Martinez* \\ Instituto de Ingeniería de Alimentos para el Desarrollo, Universitat Politecnica de Valencia, Camino de Vera s/n, 46022, Valencia, Spain
}

\section{A R T I C L E IN F O}

\section{Keywords}

Microstructure

Mechanical properties

Optical properties

E. Coli

Listeria

Water vapour permeability

\begin{abstract}
A B S T R A C T
In this study, three tannins from different sources have been used (from white peel grape (W), red peel grape (R) and from oak bark (O)) to obtain active films based on proteins (caseinate and gelatin) on the basis of their natural origin and potential antioxidant and antimicrobial activity. Films were obtained in two different ways: monolayer films, by homogeneously blending the tannins with the proteins and bilayer films, by coating the previously obtained protein film with the different tannin solutions. The microstructural, physicochemical characterisation as well as the antioxidant and antimicrobial activities of the films were analysed. The interactions developed between tannins and protein matrices determined the physico-chemical properties of the films. Significant changes were only observed in tannin-caseinate films, due to the establishment of hydrogen bonding and hydrophobic interactions, especially when using the tannin with the greatest phenolic content (W). Thus, the W tannin caseinate based films turned thicker, with markedly improved $(\mathrm{p}<0.05$ ) water solubility and WVP values and became mechanically stiffer and less stretchable. All of the films incorporating tannins exhibited remarkable antioxidant and antimicrobial activities against E.Coli and L. innocua, being the bilayer films containing W tannin the ones exhibiting the best antioxidant and antimicrobial activity against both bacteria ( 5 log of reduction), due to the greater availability of the active component when incorporated as a bilayer.
\end{abstract}

\section{Introduction}

Nowadays, the popularity of new food products free from synthetic preservatives boosts the search for natural bioactive agents, which are able to extend the shelf life of foodstuff and to prevent foodborne diseases. Many substances of differing characteristics, such as alkaloids, tannins, flavonoids and phenolic compounds coming from plant extracts, are well known to have a relevant bioactivity (Shihabudeen, Priscilla, \& Thirumurugan, 2010; Utama, Willis, Ben-Yehoshua, \& Kuek, 2002). These substances have been widely used as food flavoring agents and most of them are generally recognized as safe (GRAS) by the Food and Drug Administration, FDA. The incorporation of these bioactive substances into food coatings or packaging for food preservation has some advantages, as they act only at surface level and can be applied at any stage of the food supply chain (Rodrigues \& Han, 2000; Rodrigues, Han, \& Holley, 2002). In this sense, active coating applications for postharvest treatments or for minimally processed fruits and vegetables, cheese, meat, etc. or the development of bioactive films for food packaging purposes, are some of the reasons why the use of natural bioactive substances has recently gained in importance (Cano, Cháfer, Chiralt, \& González-Martínez, 2016).

Among bioactive substances, tannins are of particular interest because of their natural origin and antimicrobial and antioxidant capacity (Balasundram, Sundram, \& Samman, 2006; Daglia, 2012). Tannins can be extracted from different parts of plants: wood, leaves, stems and seeds (Isaza, 2007). They are complex phenolic water soluble compounds and they can form colloidal solution in alkalis, alcohol, and acetone (Akiyama, Fujii, Yamasaki, Oono, \& Iwatsuki, 2001). The phenolic compounds of the tannins are responsible for their natural antioxidant and antimicrobial activity. Their antioxidant activity depends on the structure and redox properties, which play an important role in the free radical absorption and neutralization and in the decomposition of peroxides (Balasundram et al., 2006). Akiyama et al. (2001) and Doss and Dhanabalan (2009) studied the antimicrobial activity of several tannins against different pathogen microorganisms and fungi. The mechanisms of action are very wide-ranging and they are related to the destabilization and permeation of the cytoplasmic membrane, the inhibition of the membrane extracellular enzymes and direct actions on the microbial metabolism. The deprivation of the essential micronutrients required for microbial growth (such as iron and zinc) could also explain the activity of the tannins against some microorganisms. In the literature, tannins have been found to act against wide bacterial strains, such as Salmonella, Staphylococcus aureus, Helicobacter, Escherichia coli, Clostridium, Campylobacter, Bacillus, Proteous bulgaris and Candida parapsilosis Staphylococcus aureus and Streptococcus mutans (Daglia, 2012 and Doss et al., 2009).

\footnotetext{
* Corresponding author.

E-mail addresses: amcaem@upvnet.upv.es (A. Cano); maancon1@etsiamn.upv.es (M. Andres); dchiralt@tal.upv.es (A. Chiralt); cgonza@tal.upv.es (C. González-Martinez)
} 
Previous studies revealed that sodium caseinate and gelatin form a continuous matrix, being able to incorporate different kinds of active agents. For example, carvacrol (Arrieta, Peltzer, Garrigós, \& Jiménez, 2013), alfa-tocopherol and feluric acid (Fabra, Hambleton, Talens, Debeaufort, \& Chiralt, 2011), cinnamon, ginger, clove and oregano essential oils (Acosta, 2014; Atarés, Bonilla, \& Chiralt, 2010) have been successfully incorporated, giving rise to films with proper physical and functional properties. Nevertheless, very few studies into the incorporation of tannins into any type of film have been found, to the best of our knowledge.

Interactions between tannins and proteins have been extensively studied. Complex protein-phenolic formations result from hydrogen bonding, hydrophobic interactions and electrostatic forces (Labuckas, Maestri, Perelló, Martínez, \& Lamarque, 2008; Ozdal, Capanoglu, \& Altay, 2013; Rawel, Kroll, \& Hohl, 2001). These protein-tannin interactions have been reported to affect the solubility, secondary and tertiary structure of proteins and its thermal stability (Ozdal et al., 2013), which, in turn, may modify the physical properties of the resulting protein films. In fact, some authors found an enhancement in the water repellence and mechanical properties of gluten and gelatin films due to the tannin addition (Peña, de la Caba, Eceiza, Ruseckaite and Mondragon, 2010; Girald, Teferrua and Awika, 2019). On the other hand, the affinity of tannins for proteins is known to depend on the types of proteins (hydrophobicity, isoelectric point, amino acid composition ...) and type and structure of phenolic compounds, among other factors. So, different protein-tannin combinations may lead to different changes in the structural and functional properties of both compounds. Thus, further research is needed to evaluate if these changes could positively contribute to the improvement of the protein film functionality.

The aim of the present study was to analyse the effect of the incorporation of three different tannins into sodium caseinate and gelatin based films. To this end, monolayer and bilayer tannin-rich protein films were obtained and their antioxidant and antimicrobial capacity, as well as the physical properties in terms of the optical and mechanical behaviour, moisture content, solubility and water vapour permeability, were analysed.

\section{Materials and methods}

\subsection{Materials}

Sodium caseinate (C) was purchased from Sigma Aldrich Química S.L. (Madrid, Spain) and type A bovine gelatin (G), from Sancho de Borja (Zaragoza, Spain). Glycerol (only used as a plasticizer for caseinate based films), Pentoxide di-phosphorous $\left(\mathrm{P}_{2} \mathrm{O}_{5}\right)$ and magnesium nitrate-6-hydrate $\left(\mathrm{Mn}\left(\mathrm{NO}_{3}\right)_{2}\right)$ were supplied by Panreac Química S.A. (Castellar de Vallès, Barcelona, Spain).

2,2-Diphenyl-1-pikryl-hydrazyl (DPPH), glacial acetic acid, absolute ethanol and $\mathrm{Na}_{2} \mathrm{CO}_{3}$ were provided by Panreac Química SLU (Barcelona, Spain) to carry out the different analyses.

Three different tannins coming from white peel grape (W), red peel grape (R) and oak bark (O) as active agents from Dolmar Productos Enológicos S. L. (Haro, La Rioja, Spain) were used.

\subsection{Total phenolic content of commercial tannins}

The total phenolic content was determined in triplicate following the Folin-Ciocalteu (FC) method. To perform the analyses, $100 \mu \mathrm{m}$ of appropriately diluted samples was mixed with $0.5 \mathrm{~mL}$ of Folin-Ciocalteu reagent and $1.5 \mathrm{~mL}$ of $\mathrm{Na}_{2} \mathrm{CO}_{3}$ and was completed with distilled water until $10 \mathrm{~mL}$. After $2 \mathrm{~h}$ of reaction, the absorbance of the samples was measured at $765 \mathrm{~nm}$ by means of a spectrophotometer (Evolution 201 VisibleUV, ThermoScientific, Germany). Gallic acid was used as a standard and the results were expressed as mg gallic acid $\cdot \mathrm{L}^{-1}(\mathrm{mg} \mathrm{GAE} / \mathrm{L})$.

\subsection{Preparation of films}

Two different procedures were used to obtain the films by casting: by homogeneously blending the film-forming dispersions (FFDs) composed of tannins and the proteins (monolayer films), and by coating the previously obtained protein films (pure protein) with the tannin solution (bilayer films).

As can be observed in Table 1, 11 formulations were prepared: 7 based on sodium caseinate (C) and 4 on gelatin (G). $2 \%(w / w) ~ C$ and $\mathrm{G}$ solutions were dispersed in an aqueous solution. Thereafter, $0.3 \mathrm{~g}$ of glycerol/g of protein was incorporated only in the casein FFDs. Tannins were added to the FFD in a protein:tannin ratio of $3: 1$. In the case of caseinate monolayer films $\left(\mathrm{C}^{\mathrm{m}}\right)$, the tannins were dispersed with continuous stirring until complete dissolution. Non-monolayer gelatin films were obtained as a consequence of the extensive precipitation of tannins in the presence of gelatin, as has previously been reported by Kosinska, Karamac, Penkacik, Urbalewicz, and Amarowicz (2011). The FFDs were poured into Teflon dishes containing the cast protein films, in the correct amount with which to provide a surface density of solids of $113 \mathrm{~g} \mathrm{~m}^{-2}$.

The bilayer films ( $\mathrm{C}^{\mathrm{b}}$ and $\mathrm{G}^{\mathrm{b}}$ ) were obtained in two steps: firstly, $\mathrm{C}$ and G FFDs were cast onto a Teflon plate and were partially dried for $24 \mathrm{~h}$. Afterwards, the partially-dried films were coated using a $10 \%$ tannin aqueous solution $(w / w)$, which remained as a second layer on the top of the protein film.

Films were dried at $25^{\circ} \mathrm{C}$ for $48 \mathrm{~h}$ and afterwards, peeled off the casting surface and conditioned at 53\% RH, using magnesium nitrate-6-hydrate saturated solution at $25^{\circ} \mathrm{C}$ for 2 weeks until further analysis. The film thickness was measured at six random positions with a Palmer digital micrometer to the nearest $0.0025 \mathrm{~mm}$.

\subsection{Characterisation of films}

\subsubsection{Microstructure}

The microstructural analysis of the cross section of the films was carried out using a field emission scanning electron microscope (FESEM) (Supra $^{\mathrm{TM}}$ 25-Zeiss, Germany). To this end, two replicates per formulation were analysed. To prepare the samples, films were frozen in liquid nitrogen and cryofractured to observe the cross section. Samples were fixed on copper stubs, carbon coated, and observed using an accelerating voltage of $1 \mathrm{kV}$.

\subsubsection{Film moisture content and solubility}

The moisture content (MC) of the conditioned films was analysed by drying the samples in a vacuum oven at $60^{\circ} \mathrm{C}$ for $24 \mathrm{~h}$. Later on, the pre-dried samples were placed in desiccators containing $\mathrm{P}_{2} \mathrm{O}_{5}$ at room temperature until reaching constant weight. Five replicates per film formulation were considered.

The solubility of films was determined by means of a gravimetric method. The samples were kept in distilled water in a film:water ratio of $1: 80$ for $24 \mathrm{~h}$, and later on, they were transferred to a convection oven (J.P. Selecta, S.A., Barcelona, Spain) for $24 \mathrm{~h}$ at $60^{\circ} \mathrm{C}$ to remove the free water. Afterwards, they were completely dried in a desiccator with $\mathrm{P}_{2} \mathrm{O}_{5}$ at room temperature until constant weight. Five replicates were analysed for each formulation.

\subsubsection{Water vapour permeability (WVP)}

Water vapour permeability (WVP) was evaluated in conditioned films following the gravimetric method, ASTM E96-95, by using Payne permeability cups (Payne, elcometer SPRL, Hermelle/sd Argenteau, Belgium) of $3.5 \mathrm{~cm}$ in diameter and a relative humidity gradient of $100-53 \%$. A fan placed on the top of the cup was used to reduce resistance to water vapour transport. Water vapour transmission rate measurements (WVTR) were performed at $25^{\circ} \mathrm{C}$ by means of 
the weight control of cups using an analytical balance $( \pm 0,00001 \mathrm{~g})$. To calculate WVTR, the slopes in the steady state period of the weight loss vs. time curves were determined by linear regression. WVP was calculated according to Cano et al., (2014). For each type of film, WVP measurements were taken in quadruplicate.

\subsubsection{Mechanical properties}

The mechanical properties were measured with a Universal Test Machine (TA.XT plus, Stable Micro Systems, Haslemere, England) following the ASTM standard method, D882 (ASTM, 2001, pp. 162-170). Conditioned film specimens $(2.5 \mathrm{~cm}$ wide and $10 \mathrm{~cm}$ long) were mounted in the film-extension grips (A/TG model) which were set $50 \mathrm{~mm}$ apart. The speed of the testing machine during stretching was $50 \mathrm{~mm} \mathrm{~min}^{-1}$ until breaking. Force-distance curves were obtained and transformed into Stress-Hencky curves which allowed tensile strength at break (TS, MPa), percentage of elongation at break (E, \%) and elastic modulus (EM, MPa) to be obtained. Measurements were taken at room temperature, using eight replicates per formulation.

\subsubsection{Optical properties}

The internal transmittance ( $\mathrm{Ti}$ ) of the films was quantified by means of the reflection spectrum on the white and black background from 400 to $700 \mathrm{~nm}$ with a MINOLTA spectrocolorimeter CM.36000d (Minolta Co. Tokyo, Japan) with a $30 \mathrm{~mm}$ illuminated sample area, using D65 illuminant $/ 10^{\circ}$ observer. Measurements were taken on the side of the film which was in contact with air during drying and each formulation was analysed in triplicate. Ti was calculated applying the Kubelka-Munk theory for multiple scattering to the reflection spectra, following the methodology described by Pastor, Sánchez-González, Chiralt, Cháfer, \& González-Martínez, 2013.

Gloss was measured using a flat surface gloss meter (Multi- Gloss 268, Minolta, Langenhagen, Germany) at an incidence angle of $60^{\circ}$, according to the ASTM standard, D523. Gloss measurements were taken in triplicate over a black matte standard plate. Results were expressed as gloss units, relative to a highly polished surface of standard black glass with a value close to 100 .

\subsubsection{Antioxidant activity}

The potential antioxidant power of the films was measured via the in vitro determination of the free radical scavenging effect on 2,2Diphenyl-1-picrylhydrazyl (DPPH*) radical, following the methodology described by Brand-Williams, Cuvelier, and Berset (1995) and Pastor et al. (2013). This method is based on the reduction of DPPH* in an alcoholic solution in the presence of a hydrogen-donating antioxidant, due to the formation of the non-radical form of DPPH in the reaction. In the radical form, this molecule shows absorbance at $515 \mathrm{~nm}$, which disappears after accepting an electron or hydrogen radical from an antioxidant compound, thus becoming a stable diamagnetic molecule (Matthäus, 2002). To this end, specimens of $1 \mathrm{~cm} \times 1 \mathrm{~cm}$ of dry films (containing $3.125 \mathrm{mg}$ of tannin) were previously dissolved in $50 \mathrm{~mL}$ of three food simulants (Ethanol 10\% v/v, Acetic acid 3\% v/v and Ethanol $50 \% \mathrm{v} / \mathrm{v}$ ) and maintained under magnetic stirring for $12 \mathrm{~h}$ at $25^{\circ} \mathrm{C}$. In all cases, different appropriately diluted samples were added to a methanol solution of $\mathrm{DPPH}^{*}\left(0.019 \mathrm{~g} \mathrm{~L}^{-1}\right)$. The decrease in absorbance at $25{ }^{\circ} \mathrm{C}$ was determined by using a spectrophotometer (Evolution 201 UV-Vis Spectrophotometer, Thermo Scientific, EEUU) at $515 \mathrm{~nm}$. Measurements were taken every $15 \mathrm{~min}$ until the reaction reached a plateau. The $\mathrm{DPPH}^{*}$ concentration $(\mathrm{mM})$ in the reaction medium was calculated from the calibration curve (Eq. (1)) determined by linear regression $\left(\mathrm{r}^{2}\right.$ : 0.999):

$$
\mathrm{A}_{515 \mathrm{~nm}}=14.546\left[\mathrm{DPPH}^{*}\right]-0: 005
$$

The percentage of remaining DPPH* $\left(\% \mathrm{DPPH}^{*}{ }_{\mathrm{REM}}\right)$ was calculated following equation (2)
$\% \mathrm{DPPH}^{*} \mathrm{REM}=\left[\mathrm{DPPH}^{*}\right]_{\mathrm{T}} /\left[\mathrm{DPPH}^{*}\right]_{\mathrm{T}}=0$

where.

$\left[\mathrm{DPPH}^{*}\right]_{\mathrm{T}}$ is the concentration of $\mathrm{DPPH}^{*}$ at the steady state.

$\left[\mathrm{DPPH}^{*}\right]_{\mathrm{T}=0}$ is the concentration of $\mathrm{DPPH}^{*}$ at the initial reaction time.

The percentage of remaining $\mathrm{DPPH}^{*}$ was plotted versus the molar ratio of antioxidant to $\mathrm{DPPH}^{*}$ (mg of tannin/mol DPPH*) to obtain the amount of antioxidant necessary to decrease the initial DPPH* concentration by $50 \%\left(\mathrm{EC}_{50}\right)$. This parameter was used to measure the antiradical activity of the films. $\mathrm{EC}_{50}$ values were expressed in terms of $\mathrm{g}$ of tannin per mole of DPPH*, taking into account the amount of tannins in each film.

In addition, the antioxidant activity of pure tannins dissolved in the three simulant solutions was also determined, using the same methodology.

\subsubsection{Antimicrobial properties of pure tannins and films}

Stock cultures of Escherichia coli (CECT 515) and Listeria. Innocua (CECT 910), were kept frozen $\left(-25^{\circ} \mathrm{C}\right)$ in Tryptone Soy Broth (TSB, Scharlab, Barcelona, Spain) supplemented with $30 \%$ glycerol.

Bacteria were regenerated by transferring a loopful of inoculum into $10 \mathrm{ml}$ of TSB and incubating them at $37^{\circ} \mathrm{C}$ overnight. A $10 \mu \mathrm{l}$ aliquot from the overnight culture was again transferred to $10 \mathrm{ml}$ of TSB and grown at $37^{\circ} \mathrm{C}$ to the end of the exponential phase of growth. This culture, appropriately diluted, was then used for the inoculation of the agar plates in order to obtain a target inoculum of $10^{2} \mathrm{UFC} / \mathrm{cm}^{2}$. Tryptone soy agar with $3 \% \mathrm{NaCl}$ (Panreac química, S.A., Castellar del Vallés, Barcelona, Spain) was used as a model solid food system (TSA-NaCl). Aliquots of TSA-NaCl ( $10 \mathrm{~g})$ were poured into small Petri dishes. After the culture medium solidified, a properly diluted overnight culture was inoculated on the surface.

A MTT colorimetric assay was carried out by using a 96-well microtiter plate design in order to determine the MIC of the different commercial tannins. Stock solutions of each tannin $(50 \mathrm{mg} / \mathrm{mL})$ were obtained. Diluted tannin solutions (from 0,25 to $25 \mathrm{mg}$ tannin/mL, using concentration increments of 0,5 ) were prepared from the stock solutions using TSB medium as solvent and aliquots of $100 \mu \mathrm{l}$ of each dilution were placed in their corresponding wells. Then, plates were inoculated with $100 \mu$ lof the $10^{8} \mathrm{CFU} / \mathrm{mL}$ bacterial suspension. Sterility and bacterial growth control were also prepared with non-inoculated and inoculated culture media, whereas the outer wells were left empty to prevent edge effect. After $24 \mathrm{~h}$ incubation at $37^{\circ} \mathrm{C}, 10 \mu$ of MTT reconstituted in PBS at $5 \mathrm{mg} / \mathrm{mL}$ were added to each well and incubated for $4 \mathrm{~h}$ at $37^{\circ} \mathrm{C}$. MTT is a yellow tetrazolium salt, which is reduced to a purple formazan by dehydrogenases of a live cell. Thus, the amount of formazan produced is directly proportional to the number of live cells and the MIC of the tannins can be assessed by the naked eye (Requena, 2018). In this way, the MIC values were determined as the lowest concentration of active compound at which no purple colour was observed. All the experiments were carried out in duplicate.

The antimicrobial effectiveness of films was analysed by a method adapted from Kristo, Koutsoumanis, and Biliaderis (2008) and Sánchez-González, González-Martínez, Chiralt and Chafer (2010).Films of the same diameter as the Petri dishes (containing or not an antimicrobial substance) were placed on the inoculated surfaces. Non-coated inoculated TSA-NaCl petri dishes and tannin-free films were used as controls. Plates were then sealed with parafilm to avoid dehydration and stored for 12 days at $10^{\circ} \mathrm{C}$. The microbial counts on the TSA-NaCl were examined immediately after the inoculation and periodically throughout the storage period (0-3-5-7-10-12 days). To this end, the agar was removed aseptically from Petri dishes and placed in a sterile fitter stomacher bag (Seward, West Sussex, United Kingdom) with $100 \mathrm{ml}$ of tryptone phosphate water (Sharlab S.A., 
Barcelona, Spain). The bag was homogenized for $90 \mathrm{~s}$ in a Stomacher blender (Bag Mixer 400, Seward, UK). Afterwards, serial dilutions were made and then poured onto plates for incubation, for $24-48 \mathrm{~h}$ at $37^{\circ} \mathrm{C}$, before colonies were counted. E. coli was counted in Violet Red Bilis agar (Sharlab S.A., Barcelona, Spain) plates and L. Innocua in Palcam Agar Base (Sharlab S.A., Barcelona, Spain) supplemented with Palcam Selective Supplement (Sharlab S.A., Barcelona, Spain). All the tests were performed in triplicate.

\subsection{Statistical analysis}

The results were analysed by analysis of variance (ANOVA), using the Statgraphics Centurion XV.I (Manugistics Corp., Rockville, MD). To differentiate the samples, Fisher's least significant difference (LSD) was used at the $95 \%$ confidence level.

\section{Results and discussion}

\subsection{Microstructure}

The film structure depends on the final organization and the interactions established among the different components of the FFD during the drying process. In these cases, FESEM microstructure analyses are very useful as they provide information about the internal microstructure of the films.

Fig. 1 shows only the FESEM micrographs of the cross section of the caseinate monolayer films, as the ones obtained from gelatin were very similar. Fig. 2 presents only some of the bilayer films incorporating the 3 different tannins, as again, their microstructure was similar in every case.
In general, pure C (Fig. 1) and G films (image not shown) presented a compact, homogeneous and continuous structure, in agreement with other authors working with similar matrices (Acosta, 2014; Jiménez, Fabra, Talens, \& Chiralt, 2012). The presence of a heterogeneously-fractured layer near the film surface in $\mathrm{C}$ samples revealed the progress of crystallization in this zone, probably due to the greater molecular mobility associated with the water vapour diffusion near the film surface. The presence of microcracks in both matrix films is also remarkable. This may be due to the electron impact during observation, as explained by Jiménez et al. (2012), because of the milder mechanical resistance of these samples.

The incorporation of tannins led to some differences at microstructural level (i.e., more cracks were observed). Thus, monolayer films (Fig. 1) presented intermixed compact continuous and fractured zones, due to the presence of tannin-rich areas and tannin-poor areas in the film matrix. On the other hand, in bilayer-based films, two different layers were easily observed (Fig. 2): a layer of tannin (top), mainly composed of this compound as it was added after the partial drying of the protein matrix, and a bottom second layer, mainly attributed to the continuous polymeric matrix of the film (caseinate or gelatin). The top tannin layer was compact but showed cracks as a result of its fragility. The layer containing white tannin (W) seemed to be more homogeneous and uniform than the others. No remarkable differences were observed between the microstructure of the upper layer of the films containing red $(\mathrm{R})$ or oak $(\mathrm{O})$ tannins. The degree of interaction between both layers, polymeric and tannin, will probably determine the functional and physical properties of the bilayer films.

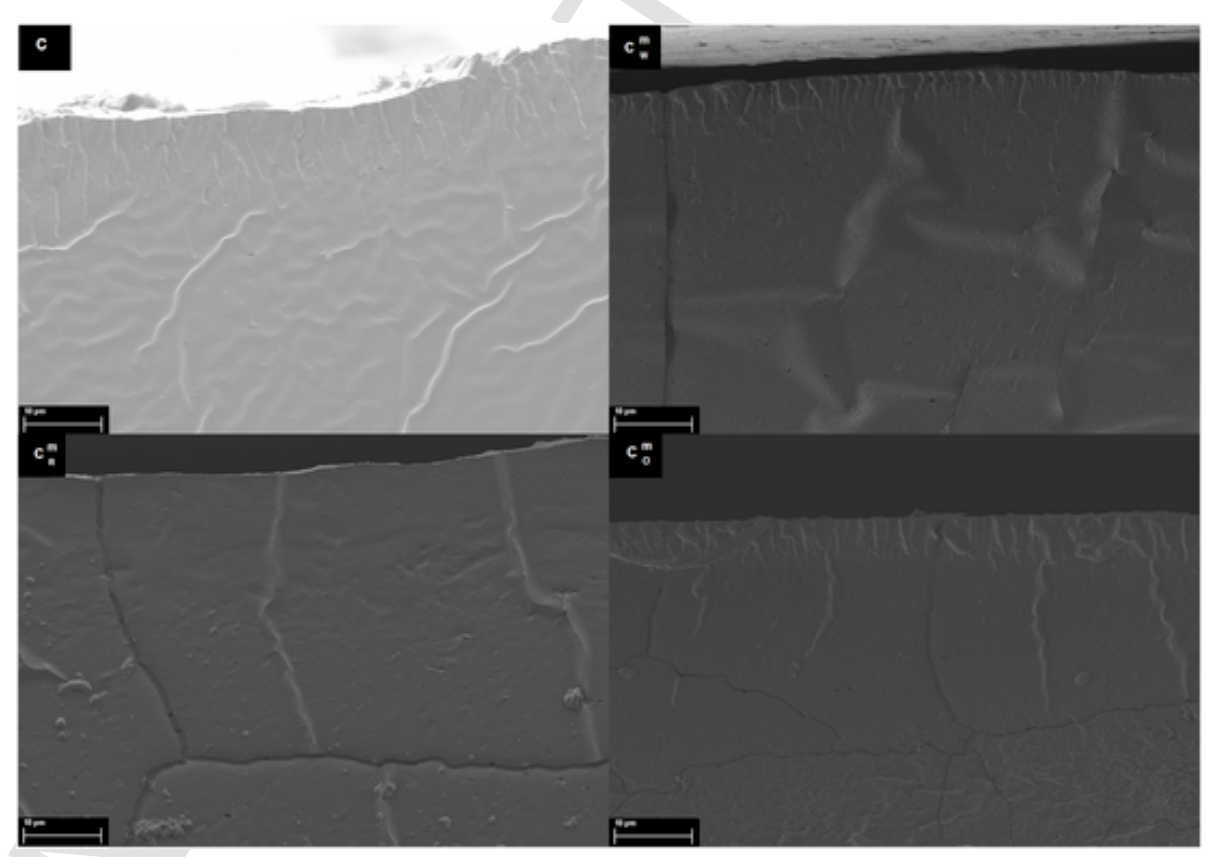

Fig. 1. FESEM micrographs of the cross section of the caseinate monolayer films containing different tannins: W: white peel grape tannin; R: red peel grape tannin; O: oak bark tannin.
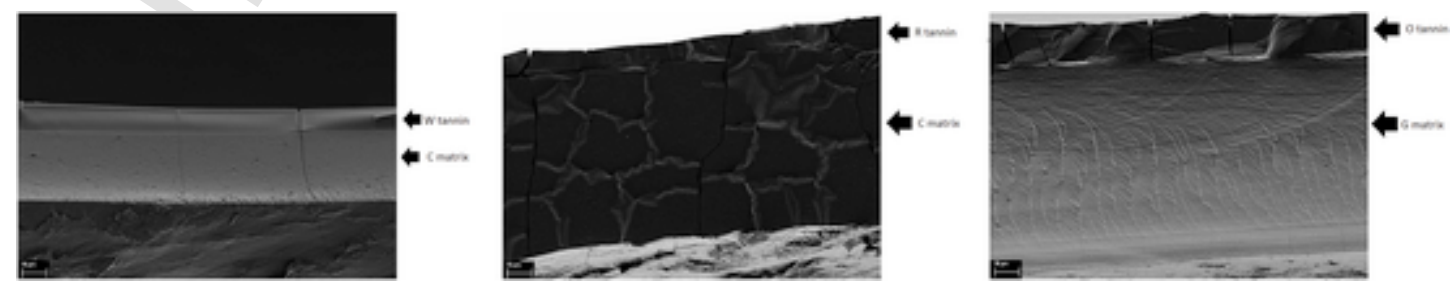

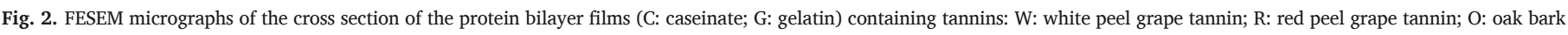
tannin. 


\subsection{Moisture content, solubility and barrier properties}

Table 3 shows the thickness, moisture content and solubility mean values and the standard deviation of the studied films, stored for 2 weeks at $25^{\circ} \mathrm{C}$ and $53 \% \mathrm{RH}$. The moisture values of the control films were $19.5 \%$ and $14.5 \%$ for $\mathrm{C}$ and $\mathrm{G}$, respectively, in agreement with the values reported in other studies (Atarés et al., 2010). After the incorporation of tannins, the films became slightly thicker in comparison with the controls, while exhibiting lower moisture contents $(\mathrm{p}<0.05)$. This reduction in the water content (around $55 \%$ and $15 \%$ for $\mathrm{C}$ and $\mathrm{G}$ films, respectively) was more marked in caseinate based films.

On the other hand, moisture content values were not significantly different $(p>0.05)$ for monolayer and bilayer films, this indicating that the manufacturing method did not affect this parameter.

As can be observed in Table 3, both C and G control films completely solubilized in water, in concordance with their hydrophilic nature (Fabra, Jimenez, Talens and Chiralt, 2009; Jridi et al., 2014). The incorporation of tannins tended to reduce the water solubility of films, as previously observed by Girard, Teferrua, and Awika (2019) and Peña, de la Cabra, Eceiza, Ruseckaite, and Mondragon (2010) when incorporating tannins to gluten and gelatin based films, respectively. These changes are consequence of the tannin-protein interactions, which have been suggested to disrupt the hydrogen bonds between protein chains by creating new hydrogen interactions between hydroxyl groups of the tannin molecule and polar groups of protein (amide carbonyl of the peptide backbone) and hydrophobic interactions (Peña et al., 2010; Yi, Cheng, \& Xing, 2006). Nevertheless, this reduction was only significant $(\mathrm{p}<0.05)$ in the case of bilayer caseinate films containing $\mathrm{W}$ tannin $\left(\mathrm{C}_{\mathrm{w}} \mathrm{b}\right)$, which reached solubility values of $28 \%$. This can be explained by taking into account, on the one hand, the greatest phenolic content of this tannin (shown in Table 2), which promotes the development of further protein-tannin interactions that could imply the re-orientation of the hydrophobic side of the polymer chains, thus reducing the film's water solubility (Ozdal et al., 2013; Peña et al., 2010). On the other hand, this behaviour was only notable in the $\mathrm{C}$ bilayer films probably due to 1 ) the abrupt gradient concentration of tannins in the interphase, as tannins were deposited on the partially dried film, and 2) the local $\mathrm{pH}$ effect in this

Table 1

Nomenclature and composition of the different formulations.

\begin{tabular}{|c|c|c|c|}
\hline Matrix & Tannin & Nomenclature & Preparation \\
\hline \multirow[t]{9}{*}{ Sodium caseinate } & - & & - \\
\hline & $\begin{array}{l}\text { White } \\
\text { (W) }\end{array}$ & $\mathrm{C}_{\mathrm{W}}{ }^{\mathrm{m}}$ & \\
\hline & Oak & $\mathrm{C}_{\mathrm{O}}^{\mathrm{m}}$ & Monolayer \\
\hline & (O) & & \\
\hline & Red & $\mathrm{C}_{\mathrm{R}}^{\mathrm{m}}$ & \\
\hline & White & $\mathrm{C}_{W}{ }^{b}$ & \\
\hline & Oak & $\mathrm{C}_{0}{ }^{\mathrm{b}}$ & Bilayer \\
\hline & (O) & & \\
\hline & Red & $C_{R}^{b}$ & \\
\hline \multirow[t]{5}{*}{ Gelatine } & - & G & - \\
\hline & White & $\mathrm{G}_{\mathrm{W}}{ }^{\mathrm{b}}$ & \\
\hline & $\begin{array}{l}\text { Oak } \\
\text { bark }\end{array}$ & $G_{O}^{b}$ & Bilayer \\
\hline & $(\mathrm{O})$ & & \\
\hline & $\begin{array}{l}\text { Red } \\
\text { (R) }\end{array}$ & $G_{R}^{b}$ & \\
\hline
\end{tabular}

Table 2

Total phenolic content and minimum inhibitory concentration (MIC) of the different commercial tannins used.

\begin{tabular}{llll}
\hline $\begin{array}{l}\text { Type of } \\
\text { tannin }\end{array}$ & $\begin{array}{l}\text { Phenolic content (g GAE/ } \\
100 \mathrm{~g})\end{array}$ & $\begin{array}{l}\text { MIC (mg/ml) } \\
\text { L.innocua }\end{array}$ & $\begin{array}{l}\text { MIC (mg/ml) } \\
\text { E.Coli }\end{array}$ \\
\hline White (W) & $41.6 \pm 0.6^{\mathrm{a}}$ & $6.5^{\mathrm{x}}$ & $12.5^{\mathrm{x}}$ \\
Red (R) & $27.5 \pm 0.3^{\mathrm{b}}$ & $20^{\mathrm{z}}$ & $25^{\mathrm{z}}$ \\
Oak bark & $24.1 \pm 0.4^{\mathrm{c}}$ & $17.5^{\mathrm{y}}$ & $17.5^{\mathrm{y}}$ \\
(O) & & & \\
\hline
\end{tabular}

a, b, c, Different superscripts within a column indicate significant differences among tannins. $(\mathrm{p}<0.05)$.

$\mathrm{x}, \mathrm{y}, \mathrm{z}$, Different superscripts within a column indicate significant differences among tannins, taking into account the no variability between the MIC values of the different replicates.

interphase. Although all tannin-caseinate film-forming dispersions exhibited a $\mathrm{pH}$ of around 5.2, the pure $\mathrm{W}$ tannin solution showed the lowest one, of around 2.5. At the tannin-casein interface, this acidic $\mathrm{pH}$ could lead to strong electrostatic interactions between the positively-charged groups of caseinate and the negatively-charged tannins, thus promoting further physical changes that mainly affected the film solubility. Interactions between phenolic compounds and proteins have been reported to depend heavily on $\mathrm{pH}$, especially when the formation of these complexes involve hydrogen bonding and electrostatic interactions (Ozdal et al., 2013; Prigent et al., 2003).

WVP values usually depend on the composition of the film's components and their spatial arrangement inside the matrix, among other factors. As can be observed in Table 3, pure C films showed greater WVP values than pure $\mathrm{G}$ films, in agreement with the higher moisture content of pure C films. Similar WVP values have been reported by Fabra, Jiménez, Atares, Talens, and Chiralt (2009) and Acosta (2014) working with net $\mathrm{C}$ and $\mathrm{G}$ films, respectively.

The addition of tannins significantly enhanced the water barrier properties of films with greater water vapour permeability values. Thus, the WVP values of C-based films significantly $(\mathrm{p}<0.05)$ decreased by around $20-50 \%$ in both monolayer and bilayer $C$ films, especially when $\mathrm{W}$ tannin was used $\left(\mathrm{C}_{\mathrm{w}}{ }^{\mathrm{m}}\right.$ and $\left.\mathrm{C}_{\mathrm{w}}{ }^{\mathrm{b}}\right)$. This improvement could be related to the closer and more uniform structure of these films, as deduced from the FESEM micrographs. On the other hand, no significant differences ( $p>0.05$ ) were found in the WVP values of bilayer G films incorporating the different tannins.

Casein bilayers exhibited lower WVP values $(p<0.05)$ than the monolayer ones, due to the significant water mass transfer resistance that the different layers can offer. This behaviour has been also

Table 3

Film's thickness, moisture content (MC), solubility (S) and water vapour permeability (WVP) of C, G and composite films. Mean values \pm standard deviation.

\begin{tabular}{|c|c|c|c|c|}
\hline Sample & Thickness (mm) & MC (\%d.b) & S (\%d.b) & $\begin{array}{l}\text { WVP }(g \cdot m m / \\
\left.\mathrm{kPa} \cdot \mathrm{h} \cdot \mathrm{m}^{2}\right)\end{array}$ \\
\hline C & $0.080 \pm 0.013^{\mathrm{a}}$ & $19.5 \pm 1.3^{\mathrm{e}}$ & $100.0 \pm 0.5^{\mathrm{d}}$ & $9.38 \pm 0.96^{g}$ \\
\hline$C_{W}{ }^{m}$ & $0.10 \pm 0.02^{d}$ & $8.6 \pm 0.4^{\mathrm{a}}$ & $97.8 \pm 1.8^{\mathrm{cd}}$ & $5.5 \pm 1.3^{\mathrm{bcd}}$ \\
\hline$C_{O}{ }^{m}$ & $0.103 \pm 0.014^{\mathrm{d}}$ & $9.6 \pm 0.5^{b}$ & $95.0 \pm 1.9^{b c}$ & $7.62 \pm 1.00^{f}$ \\
\hline$C_{R}^{m}$ & $0.995 \pm 0.019^{\mathrm{cd}}$ & $9.3 \pm 0.5^{b}$ & $97.6 \pm 0.5^{\mathrm{bcd}}$ & $7.5 \pm 0.8^{\text {ef }}$ \\
\hline$C_{W}^{b}$ & $0.10 \pm 0.02^{\mathrm{d}}$ & $9.2 \pm 0.3^{\mathrm{ab}}$ & $28 \pm 2^{\mathrm{a}}$ & $4.7 \pm 0.7^{\mathrm{abc}}$ \\
\hline$C_{O}^{b}$ & $0.096 \pm 0.018^{b c}$ & $11.7 \pm 0.3^{b}$ & $95.4 \pm 0.6^{b c}$ & $6.32 \pm 1.09 \mathrm{de}$ \\
\hline$C_{R}^{b}$ & $0.099 \pm 0.015^{\mathrm{cd}}$ & $11.81 \pm 1.09^{b}$ & $94 \pm 5^{b}$ & $6.2 \pm 1.3^{\mathrm{de}}$ \\
\hline G & $0.092 \pm 0.014^{b}$ & $14.5 \pm 0.3^{d}$ & $100.0 \pm 0.5^{\mathrm{d}}$ & $4.2 \pm 0.5^{\mathrm{ab}}$ \\
\hline $\mathrm{G}_{\mathrm{W}} \mathrm{b}$ & $0.092 \pm 0.012^{b}$ & $12.5 \pm 0.3^{c}$ & $98 \pm 4^{b c d}$ & $3.5 \pm 0.2^{\mathrm{a}}$ \\
\hline $\mathrm{G}_{\mathrm{O}} \mathrm{b}$ & $0.14 \pm 0.02^{\mathrm{e}}$ & $12.3 \pm 0.9^{c}$ & $100 \pm 2^{d}$ & $5.94 \pm 0.13^{\mathrm{cd}}$ \\
\hline $\mathrm{G}_{\mathrm{R}} \mathrm{b}$ & $0.099 \pm 0.009^{\mathrm{cd}}$ & $12.0 \pm 0.5^{c}$ & $98 \pm 3^{\mathrm{cd}}$ & $3.8 \pm 0.4^{\mathrm{a}}$ \\
\hline
\end{tabular}

a, b, c ... different superscripts within a column indicate significant differences among formulations. $(\mathrm{p}<0.05)$. 
observed by other authors working with bilayers (Muller, Gonzalez-Martinez, \& Chiralt, 2017; Sanyang, Sapuan, Jawaid, Ishak, \& Sahari, 2016).

\subsection{Mechanical properties}

The parameters of elastic modulus (EM), tensile strength at break (TS) and percentage of elongation at break (\%E) describe the mechanical behaviour of films. TS and \%E represent the film's resistance to elongation and its stretching capacity, respectively, whereas EM is a measure of the stiffness of films.

Table 4 shows the mean values of these mechanical parameters for the control and composite films, after 2 storage weeks at $25^{\circ} \mathrm{C}$ and $53 \%$ RH. Acosta (2014) reported lower EM and TS values and greater E\% values than the ones found in this work for control G films (no glycerol added). This is in agreement with the presence of plasticizer (glycerol) in the films prepared by Acosta (2014), which weakens the protein intermolecular forces and improves the molecular chain mobility.

Mechanically, control protein films behaved very differently, as C films (glycerol added) were less rigid and resistant at break (lower EM and TS values) but more stretchable (higher \%E) than G films, surely due to the presence of plasticizer in $\mathrm{C}$ films.

The incorporation of tannins to protein films significantly affected their mechanical behaviour, which depended on the protein matrix used. Thus, monolayer and bilayer tannin-rich $\mathrm{C}$ films turned stiffer $(\mathrm{p}<0.05)$ (greater EM values) and less stretchable than net $\mathrm{C}$ films. This behaviour is typical of a cross-linking agent, where the interactions established between crosslinking agent-protein enhance the mechanical response of the film (Peña et al., 2010).This effect was more pronounced in bilayer $\mathrm{C}$ films incorporating $\mathrm{W}$ tannin, surely due to their greater phenolic content (Table 2). Caseinate-tannin interactions are established, mainly through hydrogen bonding and hydrophobic interactions. Thus, the open structure of casein favours strong hydrogen binding between the carbonyl group of the peptides and the hydrogens of the hydroxyl group of polyphenols. Moreover, the high proline content of casein enhances intense hydrophobic interactions between this neutral amino acid and the aromatic rings of tannins, which are established by H-bond formation between phenolic ring groups and the bis-alkyk substituted amide nitrogen of the proline imino group (Cala et al., 2011; Cheynier, 2005). The promotion of these interactions in casein-tannin films are contributing to the modification of the mechanical response of the films, as commented on above. The tensile strength (TS) of caseinate-tannin films was not significantly modified, thus suggesting these interactions are not strong enough to enhance the film's mechanical resistance.

Table 4

Elastic modulus (EM), tensile strength at break (TS) and percentage of elongation at break (\%E) of C, G and composite films. Mean values \pm standard deviation.

\begin{tabular}{llll}
\hline MUESTRA & EM (MPa) & TS (MPa) & E (\%) \\
\hline $\mathrm{C}$ & $267 \pm 35^{\mathrm{a}}$ & $13.2 \pm 1.5^{\mathrm{a}}$ & $48 \pm 8^{\mathrm{c}}$ \\
$\mathrm{C}_{\mathrm{W}}{ }^{\mathrm{m}}$ & $613 \pm 40^{\mathrm{bc}}$ & $18.2 \pm 1.2^{\mathrm{a}}$ & $14 \pm 7^{\mathrm{b}}$ \\
$\mathrm{C}_{\mathrm{O}}{ }^{\mathrm{m}}$ & $500 \pm 48^{\mathrm{b}}$ & $14.4 \pm 1.3^{\mathrm{a}}$ & $7 \pm 3^{\mathrm{a}}$ \\
$\mathrm{C}_{\mathrm{R}}{ }^{\mathrm{m}}$ & $553 \pm 35^{\mathrm{bc}}$ & $15 \pm 2^{\mathrm{a}}$ & $18 \pm 6^{\mathrm{b}}$ \\
$\mathrm{C}_{\mathrm{W}}{ }^{\mathrm{b}}$ & $681 \pm 215^{\mathrm{c}}$ & $14 \pm 6^{\mathrm{a}}$ & $2.3 \pm 0.6^{\mathrm{a}}$ \\
$\mathrm{C}_{\mathrm{O}}^{\mathrm{b}}$ & $644 \pm 109^{\mathrm{bc}}$ & $18 \pm 5^{\mathrm{a}}$ & $15 \pm 10^{\mathrm{b}}$ \\
$\mathrm{C}_{\mathrm{R}}{ }^{\mathrm{b}}$ & $644 \pm 60^{\mathrm{bc}}$ & $19 \pm 3^{\mathrm{a}}$ & $17 \pm 12^{\mathrm{b}}$ \\
$\mathrm{G}^{\mathrm{b}}$ & $1991 \pm 135^{\mathrm{e}}$ & $98 \pm 8^{\mathrm{d}}$ & $6.5 \pm 1.2^{\mathrm{a}}$ \\
$\mathrm{G}_{\mathrm{W}}{ }^{\mathrm{b}}$ & $1965 \pm 186^{\mathrm{e}}$ & $90 \pm 18^{\mathrm{d}}$ & $6.1 \pm 1.5^{\mathrm{a}}$ \\
$\mathrm{G}_{\mathrm{O}}^{\mathrm{b}}$ & $1405 \pm 236^{\mathrm{d}}$ & $38 \pm 13^{\mathrm{b}}$ & $4.9 \pm 0.9^{\mathrm{a}}$ \\
$\mathrm{G}_{\mathrm{R}}{ }^{\mathrm{b}}$ & $1885 \pm 92^{\mathrm{e}}$ & $75 \pm 15^{\mathrm{c}}$ & $5.9 \pm 1.2^{\mathrm{a}}$ \\
\hline
\end{tabular}

a, b, c ... different superscripts within a column indicate significant differences among formulations. $(\mathrm{p}<0.05)$.
On the contrary, the tannin addition to gelatin based films pointed to the formation of a mechanically weaker network: the resistance to break significantly decreased (lower TS values than pure G films) while non-significant changes in the $\mathrm{EM}$ and $\% \mathrm{E}$ values were observed. In this case, the presence of strong electrostatic interactions between the positively charged groups of gelatin (pI around 7-9) and the negative groups of tannins caused the local precipitation of the gelatin-tannin complexes, thus preventing the development of an extensive tied network. This gelatin-tannin complex formation has also been long used to precipitate tannins from wine in the oenology industry (Sarni-Manchado, Deleris, Avallone, Cheynier, \& Moutounet, 1999).

\subsection{Optical properties}

The optical properties of the films were analysed in terms of gloss and internal transmittance $\left(\mathrm{T}_{\mathrm{i}}\right)$ at $430 \mathrm{~nm}$, as a measurement of the transparency of the films (Table 5). Both pure matrices (C, G) were highly transparent. G films were colourless, while $\mathrm{C}$ films were slightly yellow and glossier, in agreement with the results previously reported by other authors (Atarés et al., 2010; Jridi et al., 2014).

Fig. 3 shows the internal transmittance pattern for all gelatin films, together with the visual appearance of the developed films. As can be observed, the initial colour of the tannins affected both the colour coordinates and also the transparency (Ti values) of the composite films. The pure $\mathrm{W}$ tannin was lighter and more yellowish in appearance, while $\mathrm{O}$ and $\mathrm{R}$ tannins were more brownish. So, tannin-rich films turned from pale yellow to dark brown, depending on the tannin incorporated (Fig. 3). In every case, the transparency of the films significantly decreased $(p<0.05)$ due to the incorporation of tannins, especially when using the $\mathrm{R}$ and $\mathrm{O}$ tannins. In fact, films containing $\mathrm{R}$ tannins were practically opaque, reaching Ti values lower than 0.01 (Table 5).

In general, the addition of tannins significantly reduced $(\mathrm{p}<0.05)$ the gloss of the films, except in the case of bilayers containing $\mathrm{W}$ tannin. These films $\left(\mathrm{C}_{\mathrm{w}}{ }^{\mathrm{b}}\right.$ and $\left.\mathrm{G}_{\mathrm{w}}{ }^{\mathrm{b}}\right)$ were glossier than the pure films, thus indicating the presence of a uniform tannin layer with a homogeneous surface with few irregularities, as deduced from the FESEM micrographs.

\subsection{Antioxidant capacity}

The antioxidant activity of the films was evaluated by means of their dissolution in a controlled amount of three different food simulants: ethanol $10 \% \mathrm{v} / \mathrm{v}$, acetic acid $3 \% \mathrm{v} / \mathrm{v}$ and ethanol $50 \% \mathrm{v} / \mathrm{v}$.

Table 5

Internal transmittance (Ti) and gloss values of caseinate, gelatin and composite films. Mean values \pm standard deviation.

\begin{tabular}{lll}
\hline Film & $\mathrm{T}_{\mathrm{i}}(430 \mathrm{~nm})$ & Gloss \\
\hline $\mathrm{C}$ & $0.770 \pm 0.012^{\mathrm{d}}$ & $82 \pm 7^{\mathrm{f}}$ \\
$\mathrm{C}_{\mathrm{W}}{ }^{\mathrm{m}}$ & $0.54 \pm 0.02^{\mathrm{c}}$ & $51 \pm 16^{\mathrm{cd}}$ \\
$\mathrm{C}_{\mathrm{O}}{ }^{\mathrm{m}}$ & $0.02 \pm 0.014^{\mathrm{a}}$ & $30 \pm 13^{\mathrm{b}}$ \\
$\mathrm{C}_{\mathrm{R}}{ }^{\mathrm{m}}$ & $0.007 \pm 0.005^{\mathrm{a}}$ & $58 \pm 24^{\mathrm{de}}$ \\
$\mathrm{C}_{\mathrm{W}}{ }^{\mathrm{b}}$ & $0.54 \pm 0.05^{\mathrm{c}}$ & $98 \pm 3^{\mathrm{def}}$ \\
$\mathrm{C}_{\mathrm{O}}{ }^{\mathrm{b}}$ & $0.040 \pm 0.014^{\mathrm{ab}}$ & $76 \pm 21^{\text {ef }}$ \\
$\mathrm{C}_{\mathrm{R}}{ }^{\mathrm{b}}$ & $0.023 \pm 0.009^{\mathrm{a}}$ & $74 \pm 25^{\text {ef }}$ \\
$\mathrm{G}^{\mathrm{a}}$ & $0.810 \pm 0.004^{\mathrm{d}}$ & $46 \pm 14^{\mathrm{bc}}$ \\
$\mathrm{G}_{\mathrm{W}}{ }^{\mathrm{b}}$ & $0.59 \pm 0.03^{\mathrm{c}}$ & $52 \pm 20^{\mathrm{f}}$ \\
$\mathrm{G}_{\mathrm{O}}{ }^{\mathrm{b}}$ & $0.11 \pm 0.03^{\mathrm{b}}$ & $6.7 \pm 0.5^{\mathrm{a}}$ \\
$\mathrm{G}_{\mathrm{R}}{ }^{\mathrm{b}}$ & $0.030 \pm 0.007^{\mathrm{a}}$ & $7.5 \pm 1.6^{\mathrm{bc}}$ \\
\hline
\end{tabular}

a, b, c ... different superscripts within a column indicate significant differences among formulations. $(\mathrm{p}<0.05)$. 

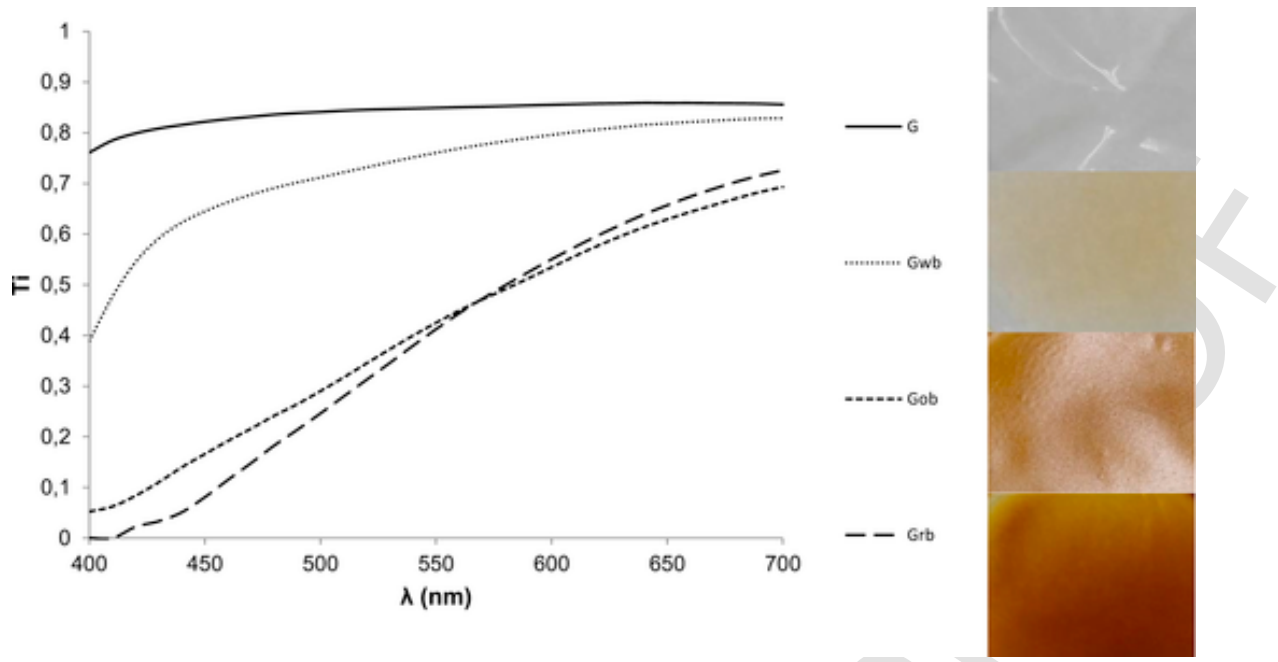

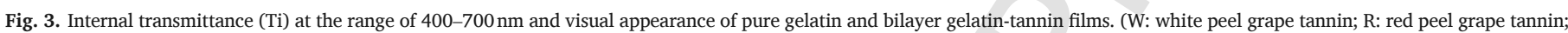
O: oak bark tannin). (For interpretation of the references to colour in this figure legend, the reader is referred to the Web version of this article.)

Once dissolved, the method described by Brand-Williams et al. (1995) based on the DPPH free radical method was applied.

From these experiments, the $\mathrm{EC}_{50}$ values were obtained, which indicate the amount of antioxidant needed to reduce the initial DPPH concentration to $50 \%$, once the steady-state of the reaction was reached (Pastor et al., 2013). Thus, the lower the $\mathrm{EC}_{50}$ values, the greater the antioxidant activity (AA) of the samples.

Table 6 shows the $\mathrm{EC}_{50}$ values for pure tannins and the different films. These values, expressed in terms of $g$ of tannins per $\mathrm{DPPH}^{*}$ moles, were obtained by taking into account the amount of tannin added in each film sample.

Pure tannins and films containing tannins were found to react quickly with the $\mathrm{DPPH}^{*}$ (fast kinetic behaviour), thus taking around $40 \mathrm{~min}$ to reach the steady state. Similar values were found by Sánchez-Moreno, Larrauri, and Saura-Calixto (1998) when working with pure gallic acid.

The pure $\mathrm{W}$ tannin exhibited the greatest antioxidant capacity (lowest $\mathrm{EC}_{50}$ value $)(\mathrm{p}<0.05)$, in agreement with its highest phenolic content, as can be observed in Table 2. Similar total phenolic

Table 6

Efficient concentration ( $\mathrm{EC}_{50}$ ) of pure tannins (white peel grape $(\mathrm{W})$, oak bark $(\mathrm{O})$, red peel grape (R)), C, G and composite films in contact with food simulants. Mean values \pm standard deviation.

\begin{tabular}{|c|c|c|c|}
\hline \multirow[t]{2}{*}{ Sample/simulant } & \multicolumn{3}{|c|}{$\mathrm{EC}_{50}(\mathrm{~g}$ of tannin/mol DPPH) } \\
\hline & ETHANOL $10 \%$ & ACETIC ACID 3\% & ETHANOL 50\% \\
\hline W & $25.10 \pm 1.04^{\mathrm{a} 1}$ & $28.6 \pm 0.12^{\mathrm{ab} 2}$ & $27.8 \pm 1.3^{\mathrm{a} 2}$ \\
\hline $\mathrm{O}$ & $40 \pm 2^{b 1}$ & $56 \pm 6^{\mathrm{fg} 2}$ & $50.4 \pm 1.7^{\mathrm{b} 12}$ \\
\hline $\mathrm{R}$ & $47 \pm 8^{b c 1}$ & $49.0 \pm 1.4^{\text {def } 12}$ & $61 \pm 8^{\mathrm{cd} 2}$ \\
\hline $\mathrm{C}_{\mathrm{W}}{ }^{\mathrm{m}}$ & $21.8 \pm 1.2^{\mathrm{a} 1}$ & $22.2 \pm 0.3^{\mathrm{a} 1}$ & $27 \pm 2^{\mathrm{a} 2}$ \\
\hline $\mathrm{C}_{\mathrm{O}}^{\mathrm{m}}$ & $74 \pm 2^{\mathrm{e} 2}$ & $97.9 \pm 0.2^{\mathrm{h} 3}$ & $53.4 \pm 1.5^{b c 1}$ \\
\hline $\mathrm{C}_{\mathrm{R}} \mathrm{m}$ & $62 \pm 3^{\mathrm{d} 1}$ & $93 \pm 7^{h 2}$ & $61.9 \pm 0.9^{\mathrm{cd} 1}$ \\
\hline $\mathrm{C}_{W}^{b}$ & $37 \pm 12^{b 1}$ & $43 \pm 12^{\text {bcd } 1}$ & $49 \pm 13^{b 1}$ \\
\hline $\mathrm{C}_{\mathrm{O}}^{\mathrm{b}}$ & $58 \pm 9^{d 1}$ & $67 \pm 10^{g 1}$ & $52 \pm 5^{\text {bc1 }}$ \\
\hline$C_{R}^{b}$ & $56 \pm 6^{\mathrm{cd} 1}$ & $53 \pm 7^{\text {ef1 }}$ & $73.48 \pm 0.13^{\mathrm{e} 2}$ \\
\hline $\mathrm{G}_{\mathrm{W}}{ }^{\mathrm{b}}$ & $38 \pm 6^{\mathrm{b} 1}$ & $38 \pm 3^{b c 1}$ & $36 \pm 8^{\mathrm{a} 1}$ \\
\hline $\mathrm{G}_{\mathrm{O}} \mathrm{b}$ & $56 \pm 6^{\mathrm{cd} 1}$ & $51 \pm 6^{\text {def } 1}$ & $57 \pm 9^{\text {bcd } 1}$ \\
\hline$G_{R} b$ & $60 \pm 4^{\mathrm{d} 2}$ & $47 \pm 2^{\text {def } 1}$ & $65 \pm 4^{\mathrm{de} 2}$ \\
\hline
\end{tabular}

a, b, c . Different superscripts within a column indicate significant differences among formulations. ( $\mathrm{p}<0.05)$.

$1,2.3$ Different superscripts within a row indicate significant differences among simulants. $(\mathrm{p}<0.05)$. contents have been found by other authors working with grape pomace (Tournour et al., 2015; Tsali \& Goula, 2018). Just as observed for pure tannins, those films incorporating $\mathrm{W}$ tannin showed the greatest AA.

As expected, non-antioxidant activity was found in control films (data not shown). In general, greater $\mathrm{EC}_{50}$ values were obtained for tannin-based films than for the pure tannins. This points to the fact that some antioxidant activity losses occurred during film formation, probably due to the promotion of tannin-protein interactions, which also limit the diffusion of the tannins to the different simulants. These results coincide with other antioxidant studies carried out with polyphenols and proteins (Ozdal et al., 2013; Von Staszewski, Pilosof, \& Jagus, 2011).

In general, bilayer caseinate films showed greater AA $(\mathrm{p}<0.05)$ than monolayer films. This is probably due to the presence of more tannins unaffected by the proteins on the surface of the bilayer films, thus favouring the preservation of their functional activity and release. The use of caseinate or gelatin as protein matrices to obtain bilayer films did not significantly affect $(\mathrm{p}>0.05)$ the antioxidant activity of the bilayers, as no significant differences were found in their $\mathrm{EC}_{50}$ values.

Finally, the multifactor ANOVA analysis showed that the type of simulant used significantly affected the AA of the pure tannins. Thus, the greatest AA was obtained when using the most polar simulant $(10 \%$ ethanol), surely due to the hydrophilic nature of the tannins. This trend $(\mathrm{p}<0.05)$ was also observed in the monolayers probably due to the greater tannin extractability capacity when using this simulant, which was favoured by the matrix hydration. On the other hand, the stability of hydrogen bonding and electrostatic interactions among tannin-proteins are less favoured in a polar environment, thus contributing to the preservation of the functionality of tannins (Damodaran, 1996). Although this trend was also observed in the bilayers, in general, the found differences were not significant ( $p>0.05$ ), surely due to the high variability obtained.

\subsection{Antimicrobial activity}

Table 2 shows the MIC values of the pure tannins against the two selected bacteria. As it can be observed, all the evaluated tannins exhibited antibacterial activity against $E$. coli and $L$. innocua, with values of MIC ranging from 6 to $25 \mathrm{mg} / \mathrm{mL}$. The antimicrobial activity of several tannins against both of these microorganisms has previously been reported by several authors (Taguri, Tanaka, \& Kouno, 2004; $\mathrm{Xu}$, Burton, Kim and Sismour, 2015). According to Chung, Wong, Wie, Huang, and Lin (1998) and Akiyama et al. (2001), the 
antimicrobial mechanisms of tannins could be due to the combination of several factors: (a) the binding and precipitation with enzymes and proteins (b) the action on the membranes of the microorganisms and (c) the complexation with metal ions, such as essential iron, which makes iron unavailable to the microorganisms. The obtained MIC against E. Coli for the W tannin is similar to that found in other studies using tannins extracted from different plants $(2-5 \mathrm{mg} / \mathrm{ml}$ ) (Taguri et al., 2004; Xu, Burton, Kim, \& Sismour, 2016).

The $\mathrm{W}$ tannin was the most effective at inhibiting the growth of both bacteria (lowest MIC). Thus, the antimicrobial activity of caseinate (both monolayer and bilayer) and gelatin films was only studied in those films incorporating this tannin, as it was the one that exhibited the best antibacterial potential.

The population viability of Listeria innocua $(\mathrm{Gram}+)$ and Escherichia coli (Gram -) in control plates and in plates coated with the different films is shown in Fig. 4 a and b, respectively. For both facultative anaerobic microorganisms, the population increased from around 2.5 to $8 \operatorname{logs}$ $\mathrm{UFC} / \mathrm{cm}^{2}$ at the end of the storage period.

No antimicrobial activity was observed for either the pure C or the G control films (tannin-free). In these films, the Listeria and E. coli growth was very similar to that of the control plates (without films).

The addition of the $\mathrm{W}$ tannin led to different antibacterial behaviour, mainly depending on the manufacturing method, which was shown to be the most significant factor. Thus, the bilayer C and G films exhibited the strongest activity against $L$. innocua and $E$. coli, which was reduced by 2 and 5 logs with respect to the control, respectively. This indicates that the more ready availability of tannins on the surface of these films (bilayer) leads to the greatest antibacterial activity. The bacteria population was kept constant during the first 5 days of incubation, so the films were found to exert a bacteriostatic effect as the tannin concentration in the agar plate (considering a total release) was estimated to be below the MIC (around $5 \mathrm{mg} / \mathrm{ml}$ ). In general, both microorganisms showed to have the same sensitivity against the $\mathrm{W}$ tannin, as no significant differences were found between them, probably because the MIC concentration was not reached.

\section{Conclusions}

Tannins from different sources have been used successfully to develop active biodegradable films. The addition of these tannins to both the $\mathrm{C}$ and $\mathrm{G}$ matrices notably affected the microstructural, physical and functional properties of the films due to the hydrogen and/or hydrophobic interactions established between tannins and proteins. These changes depended mainly on the type of tannin used, but also on the manufacturing method and protein matrix. The tannins interacted markedly with the caseinate matrix, especially when using the tannin with the highest phenolic content (W). These interactions gave rise to some positive physicochemical changes in the films, as they turned less soluble in water and acquired better water barrier properties. The mechanical changes observed due to the incorporation of tannins to caseinate films pointed to a cross-linking effect, as they became more rigid and less extensible than pure $\mathrm{C}$ films. In addition, the films incorporating $\mathrm{W}$ tannin showed the best antioxidant potential activity and remarkable antibacterial properties against $L$. innocua and E.Coli, especially when this tannin was incorporated in the films as a second layer. The obtained results offer an interesting option to obtain protein based films with improved functionalities from caseins and tannins.

\section{Acknowledgements}

The authors acknowledge the financial support from the Spanish Ministerio de Economía y Competitividad through the project AGL2016-76699-R.

\section{a) Listeria innocua}

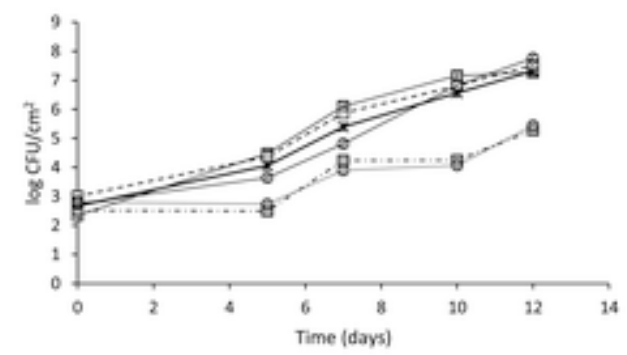

\section{b) Escherichia coli}

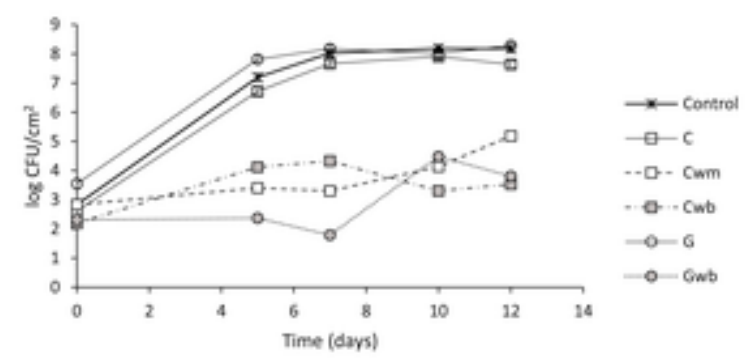

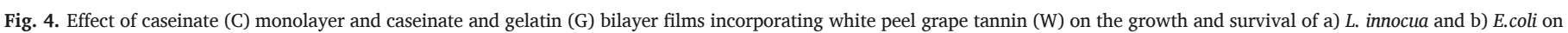
TSA-NaCl medium stored at $10^{\circ} \mathrm{C}$. 


\section{References}

Acosta, S. (2014). Propiedades de films de almidón de yuca y gelatina. Incorporación de aceites esenciales con efecto antifúngico Doctoral Thesis. Spain: Universitat Politècnica de València. Supervisors: González-Martínez, C., Cháfer, M.

Akiyama, H., Fujii, K., Yamasaki, O., Oono, T., \& Iwatsuki, K. (2001). Antimicrobial action of several tannins against Staphylococcus aureus. Journal of Antimicrobial Chemotherapy, 48, 487-491.

Arrieta, M. P., Peltzer, M. A., Garrigós, M. C., \& Jiménez, A. (2013). Structure and mechanical properties of sodium and calcium caseinate edible active films with carvacrol. Journal of Food Engineering, 114, 486-494.

ASTM (1995). Standard test methods for water vapour transmission of materials. Standard designations: E96-95 annual book of ASTM standards. (pp. 406-413). Philadelphia, PA: American Society for Testing and Materials.

ASTM (1999). Standard test methods for specular gloss. Designation (D523). Annual book of ASTM standards: 06.01. Philadelphia, PA: American Society for Testing and Materials.

ASTM (2001). Standard test method for tensile properties of thin plastic sheeting. Standard D882 Annual Book of American Standard Testing Methods. Philadelphia, PA: American Society for Testing and Materials.

Atarés, L., Bonilla, J., \& Chiralt, A. (2010). Characterization of sodium caseinate-based edible films incorporated with cinnamon or ginger essential oils. Journal of Food Engineering, 100, 678-687.

Balasundram, N., Sundram, K., \& Samman, S. (2006). Phenolic compounds in plants and agri-industrial by-products: Antioxidant activity, occurrence, and potential uses. Food Chemistry, 99, 191-203.

Brand-Williams, W., Cuvelier, M. E., \& Berset, C. (1995). Use of a free radical method to evaluate antioxidant activity. LWT-Food Science and Technology, 28, 25-30.

Cala, O., Fabre, S., Pinaus, N., Dufourc, E., Fouquet, E., \& Laguerre, M., et al. (2011). Towards a molecular interpretation of astringency: Synthesis, 3D structure, colloidal state, and human saliva protein recognition of procyanidins. Planta Medica, 77(11), $1116-1122$.

Cano, A., Jimenez, A., Gonzalez-Martinez, C., Chafer, M., \& Chiralt, A. (2014). Effect of amylose:amylopectin ratio and rice bran addition on starch films properties. Carbohydrate Polymers, 111, 543-555. doi:10.1016/j.carbpol.2014.04.075.

Cano, A., Cháfer, M., Chiralt, A., \& González-Martínez, C. (2016). Physical and antimicrobial properties of starch-PVA blend films as affected by the incorporation of natural antimicrobial agents. Foods, 5, 3. doi:10.3390/foods5010003.

Cheynier, V. (2005). Polyphenols in foods are more complex than often thought. American Journal of Clinical Nutrition, 81, 223-229.

Chung, K. T., Wong, T. Y., Wie, C. I., Huang, Y. W., \& Lin, Y. (1998). Tannins and human health: A review. Critical Reviews in Food Science and Nutrition, 36(6), 421-464.

Daglia, M. (2012). Polyphenols as antimicrobial agents. Current Opinion in Biotechnology, 23, 174-181. 19.

Damodaran, S. (1996). Amino acids, peptides, and proteins. In Fennema, O. R. (Ed.), Food chemistry (pp. 321-429). Marcel Dekker, Inc.

Doss, H. M. M., \& Dhanabalan, R. (2009). Antibacterial activity of tannins from the leaves of Solanum trilobatum Linn. Indian Journal of Science and Technology, 2(2), 41-43.

Fabra, M. J., Hambleton, A., Talens, P., Debeaufort, F., \& Chiralt, A. (2011). Effect of feluric acid and $\alpha$-tocopherol antioxidants on properties of sodium caseinate edible films. Food Hydrocolloids, 25, 1441-1447.

Fabra, M. J., Jiménez, A., Atares, L., Talens, P., \& Chiralt, A. (2009). Effect of fatty acids and beeswax addition on properties of sodium caseinate dispersions and films. Biomacromolecules, 10, 1500-1507.

Girard, A., Teferrua, T., \& Awika, J. A. M. (2019). Effects of condensed vs hydrolysable tannins on gluten film strength and stability. Food Hydrocolloids, 89, 36-43.

Isaza, J. H. (2007). Taninos o polifenoles vegetales. Scientia et Technica Year XIII, 33, 13-18.

Jiménez, A., Fabra, M. J., Talens, P., \& Chiralt, A. (2012). Effect of sodium caseinate on properties and ageing behaviour of corn starch based films. Food Hydrocolloids, 29, 265-271.
Jridi, M., Hajji, S., Ben Ayed, H., Lassoued, I., Mbarek, A., \& Kammoun, M., et al. (2014). Physical, structural, antioxidant and antimicrobial properties of gelatin-chitosan composite edible films. International Journal of Biological Macromolecules, 67, 373-379.

Kosinska, A., Karamac, M., Penkacik, K., Urbalewicz, A., \& Amarowicz, R. (2011). Interactions between tannins and proteins isolated from broad bean seeds (Vicia faba Major) yield soluble and non-soluble complexes. European Food Research and Technology, 233, 213-222.

Kristo, E., Koutsoumanis, K. P., \& Biliaderis, C. G. (2008). Thermal, mechanical and water vapor barrier properties of sodium caseinate films containing antimicrobials and their inhibitory action on Listeria monocytogenes. Journal of Food Hydrocolloids, 22, 373-386.

Labuckas, D. O., Maestri, D. M., Perelló, M., Martínez, M. L., \& Lamarque, A. L. (2008). Phenolics from walnut (Juglans regia L.) kernels: Antioxidant activity and interactions with proteins. Food Chemistry, 107, 607-612.

Matthäus, B. (2002). Antioxidant activity of extracts obtained from residues of different oilseeds. Journal of Agricultural and Food Chemistry, 50, 3444-3452.

Muller, J., Gonzalez-Martinez, C., \& Chiralt, A. (2017). Poly(lactic) acid (PLA) and starch bilayer films, containing cinnamaldehyde, obtained by compression moulding. European Polymer Journal, 95, 56-70.

Ozdal, T., Capanoglu, E., \& Altay, F. (2013). A review on protein-phenolic interactions and associated changes. Food Research International, 51, 954-970.

Pastor, C., Sánchez-González, L., Chiralt, A., Cháfer, M., \& González-Martínez, C. (2013) Physical and antioxidant properties of chitosan and methylcellulose based films containing resveratrol. Food Hydrocolloids, 30, 272-280.

Peña, C., de la Cabra, K., Eceiza, A., Ruseckaite, R., \& Mondragon, I. (2010). Enhanc ing water repellence and mechanical properties of gelatin films by tannin addition. Biosource Technology, 101, 6836-6842.

Prigent, S. V. E., Gruppen, H., Visser, A. J. W. G., Van Koningsveld, G. A., De Jong, A. H., \& Voragen, A. G. J. (2003). Effects of non-covalent interactions with 5-O-caffeoylquinic acid (chlorogenic acid) on the heat denaturation and solubility of globular proteins. Journal of Agricultural and Food Chemistry, 51, 5088-5095.

Rawel, H. M., Kroll, J., \& Hohl, U. C. (2001). Model studies on reactions of plant phenols with whey proteins. Nahrung-Food, 45(2), 72-81.

Requena, R. (2018). Multilayer biodegradable active films based on PHBV for food packaging Doctoral thesis. Spain: Universitat Politecnica de Valencia.

Rodrigues, E. T., \& Han, J. H. (2000). Antimicrobial whey protein films against spoilage and pathogenic bacteria. IFT annual meeting: Book of abstracts (p. 191). Chicago, IL: Institute of Food Technologists.

Rodrigues, E. T., Han, J. H., \& Holley, R. A. (2002). Optimized antimicrobial edible whey protein films against spoilage and pathogenic bacteria. IFT annual meeting: Book of abstracts (p. 252). Chicago, IL: Institute of Food Technologists.

Sánchez-González, L., González-Martínez, C., Chiralt, A., \& Cháfer, M. (2010). Physical and antimicrobial properties of chitosan-tea tree essential oil composite films. Journal of Food Engineering, 98, 443-452.

Sánchez-Moreno, C., Larrauri, J. A., \& Saura-Calixto, F. (1998). A procedure to measure the antiradical efficiency of polyphenols. Journal of the Science of Food and Agriculture, 76, 270-276.

Sanyang, M. L., Sapuan, S. M., Jawaid, M., Ishak, M. R., \& Sahari, J. (2016). Development and characterization of sugar palm starch and poly(lactic acid) bilayer films. Carbohydarte Polymer, 146, 36-45.

Sarni-Manchado, P., Deleris, A., Avallone, S., Cheynier, V., \& Moutounet, M. (1999) Analysis and characterization of wine condensed tannins precipitated by proteins used as fining agent in enology. American Journal of Enology and Viticulture, 50, 81-86.

Shihabudeen, M. H., Priscilla, D. H., \& Thirumurugan, K. (2010). Antimicrobial activity and phytochemical analysis of selected Indian folk medicinal plants. International Journal Pharmaceutical Science and Research, 1, 430-434.

Taguri, T., Tanaka, T., \& Kouno, I. (2004). Antimicrobial activity of 10 different plant polyphenols against bacteria causing food-borne disease. Biological and Pharmaceutical Bulletin, 27, 1965-1969.

Tournour, H. H., Segundo, M. A., Magalhães, L. M., Barreiros, L., Queiroz, J., \& Cunha, L. (2015). Valorization of grape pomace: Extraction of bioactive phenolic with antioxidant properties. Industrial Crops and Products, 74, 397-406.

Tsali, A., \& Goula, A. M. (2018). Valorization of grape pomace: Encapsulation and storage stability of its phenolic extract. Powder Technology, 340, 199-207. 
Utama, I. M. S., Willis, R. B. H., Ben-Yehoshua, S., \& Kuek, C. (2002). In vitro efficacy of plant volatiles for inhibiting the growth of fruit and vegetable decay microorganisms. Journal of Agricultural and Food Chemistry, 50, 6371-6377.

Von Staszewski, M. V., Pilosof, A. M. R., \& Jagus, R. J. (2011). Antioxidant and antimicrobial performance of different Argentinean gren tea varieties as affected by whey proteins. Food Chemistry, 125, 186-192.
Xu, Y., Burton, S., Kim, C., \& Sismour, E. (2016). Phenolic compounds, antioxidant and antibacterial properties of pomace extracts from four Virgini-grown grape varieties. Food Sciences and Nutrition, 4(1), 125-133.

Yi, K., Cheng, C., \& Xing, F. (2006). Gelatin/tannin complex nanospheres via molecular assembly. Journal of Applied Polymer Science, 101, 12577-12585. 